\title{
Philosophiques
}

\section{Note de la rédaction}

Volume 11, numéro 1, avril 1984

URI : https://id.erudit.org/iderudit/203243ar

DOI : https://doi.org/10.7202/203243ar

Aller au sommaire du numéro

Éditeur(s)

Société de philosophie du Québec

ISSN

0316-2923 (imprimé)

1492-1391 (numérique)

Découvrir la revue

Citer ce document

(1984). Note de la rédaction. Philosophiques, 11(1), 111-111.

https://doi.org/10.7202/203243ar

Ce document est protégé par la loi sur le droit d'auteur. L'utilisation des services d'Érudit (y compris la reproduction) est assujettie à sa politique d'utilisation que vous pouvez consulter en ligne.

https://apropos.erudit.org/fr/usagers/politique-dutilisation/
Cet article est diffusé et préservé par Érudit.

Érudit est un consortium interuniversitaire sans but lucratif composé de l'Université de Montréal, l'Université Laval et l'Université du Québec à Montréal. Il a pour mission la promotion et la valorisation de la recherche. https://www.erudit.org/fr/ 


\section{ÉGALITÉ, JUSTICE ET DIFFÉRENCE}

\section{NOTE DE LA RÉDACTION}

Philosophiques présente à ses lecteurs, dans le présent numéro, les quatre premiers d'une série de neuf textes produits par les membres d'une équipe de recherche travaillant au Département de philosophie de l'Université de Montréal. Les autres textes paraîtront dans notre prochain numéro, soit celui d'octobre 1984 . 